\title{
Serum PSA And Immunohistochemical Expression Of p53 In Prostatic Specimens
}

\author{
Dr. Yudhvir Singh ${ }^{1}$,Dr. Uma Sharma ${ }^{2}$, Dr. Pawan Tiwari ${ }^{3}$,Dr. Arun Saxena ${ }^{4}$ \\ ${ }^{1,2,4}$ (Department Of Pathology, SGT Medical College, Hospital And Research Centre, SGT University \\ Gurugram, Haryana, INDIA) \\ ${ }^{3}$ (Department Of Surgery, SGT Medical College, Hospital And Research Centre, SGT University \\ Gurugram, Haryana, INDIA)
}

\begin{abstract}
Diseased prostate is a great concern in the geriatric age group. The two conditions most frequently observed in prostate are Benign Prostatic Hyperplasia (BPH) and Carcinoma prostate. The incidence of both conditions increase with advancing age and are an important growing health problem with often unpredictable clinical course. Specific molecular mechanisms are involved in the development and progression of prostate cancer as well as in BPH. A total of 70 cases were studied histologically. Out of 70 cases, 58 cases were diagnosed as Benign Prostatic Hyperplasia (BPH) and 12 cases were diagnosed as carcinoma prostate. Serum PSA levels of all the 70 cases were evaluated and correlation were made with immunohistochemical (IHC) marker p53. The difference of serum PSA levels in the two prostatic lesions, BPH and carcinoma prostate were highly significant. The p53 IHC staining was negative in all the 58 cases of BPH and was positive in all the 12 cases of carcinoma prostate. It can be concluded that the IHC expression of p53 is significantly up-regulated in malignant lesions along with serum PSA. More research and developments is to be done in this area of tumor suppressor genes and cancer cell biology.
\end{abstract}

Keywords: Prostate, Benign Prostatic Hyperplasia, Carcinoma Prostate, p53, IHC

\section{Introduction}

Ageing is an inevitable phenomenon with both structural and functional changes in the organs of human body. One of the organ undergoing these senile changes is prostate gland. The word "Prostate" derived from a Latin word "prostatēs" which means guardian or something standing in front (of the bladder). ${ }^{[1]}$

The glandular elements or zones, which produce and drain prostatic secretions into the urethra, account for approximately $70 \%$ of the total prostate bulk with the fibromuscular stroma, comprising of connective tissue and smooth muscle, making up the remaining $30 \%$. The prostate gland contains three major glandular regions, the peripheral zone, the central zone, and the transition zone which differ histologically and biologically. Frequent deviations from normal histology include post-inflammatory atrophy, basal cell hyperplasia, benign nodular hyperplasia, atypical adenomatous hyperplasia, and duct-acinar dysplasia. BPH is the most frequent lesion in aging males and one of the most common chronic conditions in the male population, with a histological prevalence at autopsy of 50\% in men aged $50-60$ years and of $90 \%$ over 80 years old. ${ }^{[3]}$

Prostate adenocarcinoma is the most common malignant tumor in men. The prostate cancer incidence increases from $20 \%$ in patients between 50-60 years to approximately $70 \%$ between $70-80$ years. Increased rate of detection of prostatic disease may be due to increased availability of prostatic-specific antigen (PSA) measurement. Elevated blood levels of PSA occur in association with localized as well as advanced cancer. PSA level can rise dramatically with prostatic infection, but it return to the normal reference range after the infection has healed. PSA is organ specific, but not cancer specific. The p53 is a tumor suppressor gene, with mutations occurring in carcinoma, Prostatic Intraepithelial Neoplasia, Benign Prostatic Hyperplasia. The p53 tumor suppressor gene links cell damage with DNA repair, cell cycle arrest and apoptosis. With loss of function of p53, DNA damage goes unrepaired, and leads to malignant transformation. Mutation of tumor suppressor gene is one of the most common genetic alterations in malignant tumors including urological neoplasm. ${ }^{[7]}$ Positive immunostaining for $\mathrm{p} 53$ has been associated with the detection of the more stable mutant protein and predicts the presence of p53 gene mutation with about $80 \%$ to $90 \%$ accuracy. Despite high incidence of carcinoma prostrate, lack of biological information in this field results in a lot of disagreements about the early steps of its clinical assessment and screening the patients. ${ }^{[9]}$

This study was done to find the correlation between Gleason's grading prostatic carcinoma and serum PSA with tumour suppressor protein $\mathrm{p} 53$ as prognostic factors in prostatic specimens.

\section{Material And Methods}

This prospective study was carried out in the department of pathology on seventy patients. Brief clinical data were noted from case records, which include age, presenting features, and type of surgical procedure 
performed. All types of prostatic specimens including TURP, radical prostatectomy were considered in this study. Inadequate biopsies and poorly preserved prostatic specimens were excluded. Serum PSA levels of the patients were measured with the ELISA machine "Centaur Advia Cp". H\&E stained sections were studied under light microscope and classified into benign and malignant lesions. Carcinoma cases were histologically graded according to Gleason's grading system. Associated prostatic tissue changes like tumor invasion, PIN, prostatitis and others if any, were also analyzed. Immunohistochemical (IHC) profile of the tumor was assessed by subjecting one section each from a representative block to p53 immunostain. Positive and negative controls were run simultaneously. Positive control for p53 was carcinoma colon. Negative control was employed by substituting primary antibody with antibody of irrelevant specificity. The interpretation of p53 expression was done by considering strong brown nuclear immunoreactivity as positive staining.Immunoquantitation each slide was done at 40x magnification to find areas with maximum positive cells. Then these areas were examined at 400x magnification and the percentage of positive cells to total cells was calculated. At least 500 cells were calculated and only the cells that were definitely positive for the desired marker were considered.

In case of p53 the tumors were divided into four groups as suggested by Petrescu et al. ${ }^{[10]}$

0 - No nuclear staining seen

1 - Less than $10 \%$ of the tumor cell nuclei were stained

2 - More than $10 \%$, but less than $33 \%$ of nuclei were stained

3 - More than $33 \%$ of nuclei were stained

\section{Results}

The observations were tabulated and analyzed by using software for windows. The seventy patients selected for the study were in the age group of 46-90 years with class interval of 5 years and a mean age of 62 years. The youngest patient was 46 years old and eldest was 88 years old. The maximum number of patients were in $7^{\text {th }}$ decade $(48.57 \%)$ in this study (Table1).

Table 1. Distribution Of Total Cases According To Age Group

\begin{tabular}{|c|c|c|}
\hline Age Groups (Years) & No. of Cases $(\mathrm{n}=70)$ & $\%$ \\
\hline $46-50$ years & 3 & 4.29 \\
\hline $51-55$ years & 9 & 12.86 \\
\hline $56-60$ years & 16 & 22.86 \\
\hline $61-65$ years & 25 & 35.71 \\
\hline $66-70$ years & 9 & 12.86 \\
\hline $71-75$ years & 2 & 2.86 \\
\hline $76-80$ years & 3 & 4.29 \\
\hline $81-85$ years & 1 & 1.43 \\
\hline $86-90$ years & 2 & 2.86 \\
\hline Total & 70 & 100 \\
\hline Mean \pm S.D. (Years) & \multicolumn{2}{|c}{} \\
\hline
\end{tabular}

Of the total 70 cases, 58 (82.8\%) were categorized as Benign Prostatic Hyperplasia (BPH) and 12 (17.1\%) were of carcinoma prostate based histopathology of the specimens. The correlation of serum PSA levels in BPH and carcinoma prostate revealed that the PSA level was below $4 \mathrm{ng} / \mathrm{ml}$ (i.e. within normal limits) in 33 cases of BPH group (56.8\%). In 25 cases (43.1\%), the levels were raised but not above $10 \mathrm{ng} / \mathrm{ml}$. In all carcinoma prostate cases the serum PSA levels was raised above $10 \mathrm{ng} / \mathrm{ml}$. except in one case which was having serum PSA level of $7.2 \mathrm{ng} / \mathrm{ml}$. The $\mathrm{p}$ value is $<0.05$ depicts significant difference. (Table 2)

Table 2. Serum Prostatic Specific Antigen (PSA) Levels In BPH And Carcinoma Prostate Cases

\begin{tabular}{|c|c|c|c|c|}
\hline Serum PSA level & $\begin{array}{c}\mathrm{BPH}(\mathrm{n}=58) \\
\{\text { No. of cases \% }\end{array}$ & $\begin{array}{c}\text { Carcinoma Prostate } \\
(\mathrm{n}=12) \\
\{\text { No. of cases } \%\}\end{array}$ & $\begin{array}{c}\mathrm{P} \\
\text { Value }\end{array}$ & Result \\
\hline$<4 \mathrm{ng} / \mathrm{ml}$ & $33(56.8 \%)$ & $0(0 \%)$ & \multirow{7}{*}{$<0.05$} & \multirow{7}{*}{$\begin{array}{l}\text { Highly } \\
\text { Significant }\end{array}$} \\
\hline $4-10 \mathrm{ng} / \mathrm{ml}$ & $25(43.1 \%)$ & $1(8.3 \%)$ & & \\
\hline $10-20 \mathrm{ng} / \mathrm{ml}$ & $0(0 \%)$ & $7(58.3 \%)$ & & \\
\hline $20-30 \mathrm{ng} / \mathrm{ml}$ & $0(0 \%)$ & $1(8.3 \%)$ & & \\
\hline $30-40 \mathrm{ng} / \mathrm{ml}$ & $0(0 \%)$ & $0(0 \%)$ & & \\
\hline $40-50 \mathrm{ng} / \mathrm{ml}$ & $0(0 \%)$ & $1(8.3 \%)$ & & \\
\hline$>50 \mathrm{ng} / \mathrm{ml}$ & $0(0 \%)$ & $2(16.6 \%)$ & & \\
\hline
\end{tabular}


Out of total 58 cases, in 33 cases $(56.8 \%)$, the level was below $4 \mathrm{ng} / \mathrm{ml}$, whereas in 25 cases $(43.2 \%)$ it was above. It was noted that in 11 cases serum PSA level was raised upto $6 \mathrm{ng} / \mathrm{ml}$, in 13 cases (22.4\%) upto 8 $\mathrm{ng} / \mathrm{ml}$ and; so it is in the range of $8-10 \mathrm{ng} / \mathrm{ml}$ and only in one case $(1.72 \%)$ it was $8.6 \mathrm{ng} / \mathrm{ml}$. The histological changes of stromal inflammation (acute \& chronic) and basal cell hyperplasia noticed in the BPH cases. (Table 3)

Table 3. Correlation Of Serum Prostatic Specific Antigen (PSA) Levels With Histomorphological Changes In BPH Patients $(\mathrm{N}=58)$.

\begin{tabular}{|c|c|c|c|c|}
\hline Serum PSA level & $\begin{array}{c}\text { No. of cases } \\
(\%)\end{array}$ & \multicolumn{2}{|l|}{ Stromal Inflammation } & $\begin{array}{c}\text { Basal Cell } \\
\text { Hyperplasia } \\
(\%)\end{array}$ \\
& & & \\
& & Acute $(\%)$ & Chronic $(\%)$ & \\
\cline { 3 - 5 } & & 0 & $5(20 \%)$ & $5(38.4 \%)$ \\
\hline$<4 \mathrm{ng} / \mathrm{ml}$ & $33(56.8 \%)$ & $1(25 \%)$ & $8(32 \%)$ & $4(30.7 \%)$ \\
\hline $4-6 \mathrm{ng} / \mathrm{ml}$ & $11(18.9 \%)$ & $2(50 \%)$ & $11(44 \%)$ & $3(23 \%)$ \\
\hline $6-8 \mathrm{ng} / \mathrm{ml}$ & $13(22.4 \%)$ & $1(25 \%)$ & $1(4 \%)$ & $1(7.6 \%)$ \\
\hline $8-10 \mathrm{ng} / \mathrm{ml}$ & $1(1.72 \%)$ & 4 & 25 & 13 \\
\hline Total & 58 & &
\end{tabular}

The p53 expression is seen by the brown color on the epithelial nuclei on immunostaining with p53 antigen. These cells are taken as positive. The number of positive compared to the negatively stained nuclei was evaluated for IHC scoring as 0 : no staining, 1: $<10 \%$ nuclei stained, $2: 10 \%-33 \%$ nuclei stained, $3:>33 \%$ nuclei stained. It was observed that all carcinoma cases were positive for p53 expression. IHC score $1(<10 \%$ nuclei stained) was seen in 5 cases $(41.6 \%)$, IHC score 2 (10-33\% nuclei stained) in 4 cases $(33.3 \%)$, IHC score 3 (> $33 \%$ nuclei stained) was in 3 cases $(25 \%)$.

Table 4. \% Expression Of p53 In Carcinoma Prostate. (N=12)

\begin{tabular}{|c|c|c|}
\hline $\mathrm{p} 53$ expression & No. of cases $(\mathrm{n}=12)$ & $\%$ \\
\hline $0(0 \%)$ & 0 & 0 \\
\hline $1(10 \%)$ & 5 & 41.67 \\
\hline $2(10-33 \%)$ & 4 & 33.33 \\
\hline $3(>33 \%)$ & 3 & 25.00 \\
\hline Total & 12 & 100 \\
\hline
\end{tabular}

The individual 12 carcinoma cases with their serum PSA levels, the histological grade (as per Gleason's grading) and the p53 IHC score with relative intensity of IHC staining are depicted in Table

Table 5. Carcinoma prostate cases depicting PSA levels, gleason's grading, p53 ihc score and \% intensity of ihc staining

\begin{tabular}{|c|c|c|c|c|c|}
\hline Cases & Age (in years) & $\begin{array}{c}\text { PSA value } \\
(\mathrm{ng} / \mathrm{ml})\end{array}$ & Gleason's Grade & IHC Score & $\begin{array}{c}\% \\
\text { Intensity }\end{array}$ \\
\hline 1 & 80 & 47.7 & $4+5=9$ & 3 & $\mathrm{H}$ \\
\hline 2 & 78 & 15.7 & $4+3=7$ & 2 & $\mathrm{~L}$ \\
\hline 3 & 88 & 10.8 & $4+3=7$ & 2 & $\mathrm{~L}$ \\
\hline 4 & 86 & 100.4 & $5+4=9$ & 3 & $\mathrm{H}$ \\
\hline 5 & 67 & 25.5 & $2+1=3$ & 1 & $\mathrm{~L}$ \\
\hline 6 & 77 & 50.2 & $4+4=8$ & 3 & $\mathrm{H}$ \\
\hline 7 & 67 & 7.2 & $3+4=7$ & 1 & $\mathrm{~L}$ \\
\hline 8 & 75 & 15.7 & $3+3=6$ & 1 & $\mathrm{~L}$ \\
\hline 9 & 66 & 13.2 & $4+4=8$ & 2 & $\mathrm{M}$ \\
\hline 10 & 83 & 10.8 & $3+4=7$ & 1 & $\mathrm{~L}$ \\
\hline 11 & 75 & 12.7 & $3+4=7$ & 1 & $\mathrm{~L}$ \\
\hline 12 & 65 & 12.8 & $4+4=8$ & 2 & $\mathrm{M}$ \\
\hline
\end{tabular}

There was no p53 expression in 58 BPH cases, where as all 12 cases of carcinoma prostate shows p53 IHC positive staining out of total 70 cases. The result is highly significant ( $\mathrm{p}$ value $<0.001$ ).

\section{Discussion}

The senile prostrate has two type of changes, the benign prostatic hyperplasia and carcinoma prostrate. The BPH cases were seen up to 70 years of age while carcinoma prostate were seen mostly in higher age group. This may be because; BPH causes more pressure symptoms and thus patient present early. The youngest patient in BPH group was 46 years old and the oldest one was 70 years. In cases of carcinoma, youngest patient was 65 years old and eldest one was 88 years old. Robbins et al reported that the cases of carcinoma prostate progressively rise after the age of 50 years with a peak incidence at and above 70 years. Patients with malignant 
lesions were in higher age group as compared to patients with benign lesions. ${ }^{[11]}$ Clements et al also suggested the similar findings by stating that one half of all cases of carcinoma prostate occur in men older than 75 years. [12] Ackerman et al observed that almost $75 \%$ of cases of prostatic carcinoma are of age 65 years or more, although these tumors can be seen in younger adults. In the present study, observations are similar with above mentioned studies. The serum PSA levels in this study was abnormally raised in 25 cases of BPH, while 33 cases of BPH had serum PSA levels $<4 \mathrm{ng} / \mathrm{ml}$. On comparing these values with their relative age groups, 24 cases had definitely high serum PSA value ( 9 cases in 50-59 age group \& 15 cases in 60-69 age group). There was a discrepancy of only one patient where the value of serum PSA was $4.2 \mathrm{ng} / \mathrm{ml}$ and the patient age was 62 years, who could have been classed as having normal serum PSA level as per age.

The age of all cancer patients was above 65 years and their serum PSA levels were significantly high. Various studies have correlated the increased PSA levels in association with carcinoma prostate, ${ }^{[13-18]}$ but there was no definitive demarcation, as some carcinomas has less than $4 \mathrm{ng} / \mathrm{ml}$ serum PSA level.

Thompson et al undertook a screening for prevalence of prostate carcinoma in a large series of 2950 normal men with a serum PSA level $<4 \mathrm{ng} / \mathrm{ml}$. These person were followed up for 7 years and then finally subjected to prostatic biopsy. They found 449 men $(15.2 \%)$ had prostatic carcinoma and 67 of them also had high Gleason's score of 7 or above. Hence, they concluded that high serum PSA levels alone are not indicative of prostatic carcinoma. Shih et al studied the serum PSA levels in 28 cases of BPH and 20 cases of prostatic adenocarcinoma. They found that in carcinomas, the serum PSA values were raised more (cut off level being 10 $\mathrm{ng} / \mathrm{ml}$ ) and stated that serum PSA is an important investigation to monitor the prognosis. ${ }^{[20]}$ Matikainen et al in 1999 and Valeri et al in 2002 in separate studies used the serum PSA levels with a cut off value of $4 \mathrm{ng} / \mathrm{ml}$ to screen the relatives of carcinoma prostate patients. ${ }^{[21,22]}$ According to Ackerman et al almost half the patients with prostatic carcinoma have serum PSA > $10 \mathrm{ng} / \mathrm{ml}$. In the routine pathological examination of carcinoma prostate, the Gleason's grading is a great help to predict the aggressiveness of the tumor. It is widely used as a prognostic marker and guides the therapeutic approach. Also with the knowledge of the recent molecular aspects, the over-expressed p53 in prostatic carcinoma is a good marker to assess the prognosis and management of the cases.

In the present study, all carcinoma cases had serum PSA levels above $4 \mathrm{ng} / \mathrm{ml}$. There was a statistically significant difference between BPH and carcinoma prostate cases. There were 58 cases of BPH out of total 70 cases. 33 cases $(56.8 \%)$ of BPH had serum PSA levels within normal range i.e. $<4 \mathrm{ng} / \mathrm{ml}$. Rest 25 cases $(43.1 \%)$ had increased levels of serum PSA. One case had a level $8.6 \mathrm{ng} / \mathrm{ml}$. This case histologically had acute \& chronic inflammation, Basal cell hyperplasia and Grade 1 PIN (Prostate Intra-epithelial Neoplasia) changes. The remaining 24 cases $(41.1 \%$ ) had serum PSA level increased, but not more than $7.5 \mathrm{ng} / \mathrm{ml}$. On correlating, it was found that 20 out of 25 cases $(80 \%)$ had stromal inflammation and 8 out of 25 cases $(32 \%)$ had basal cell hyperplasia. The findings were statistically not significant but consistent with increased serum PSA levels reported in chronic prostatitis.

Histologically, all malignant prostate cases were adenocarcinomas. Gleason's grading was done and tumors were classified as well differentiated (WD, grade 2-4), moderately differentiated (MD, grade 5-7) and poorly diiferentiated (PD, grade 8-10). In the present study, there was only 1 case $(8.3 \%)$ of well differentiated, 6 cases $(50 \%)$ of moderately differentiated and 5 cases $(41.6 \%)$ of poorly differentiated tumors. The importance of Gleason's grade in carcinoma prostate is emphasized as the higher the grade, the tumor is more aggressive and has poor prognosis. In present study, all cases were subjected to IHC staining for p53. Among 58 cases of $\mathrm{BPH}, \mathrm{p} 53$ was expressed in none $(0 \%)$ cases, while in 12 carcinoma cases it was expressed in all $(100 \%)$ of them. p53 expression was significantly up-regulated in prostatic cancer $(\mathrm{p}=0.001)$ as compared with benign prostatic hyperplasia (BPH).In this study, a good correlation between Gleason's grade and p53 IHC score were seen in carcinoma prostate cases. The higher the Gleason's grade (poorly differentiated, 8-10), higher was the IHC score and in lower grade (well differentiated, 2-4) tumor, IHC score and also the staining intensity was low.

In summary the present study emphasizes the role of increased serum PSA levels in carcinoma prostate cases. This investigation is related to the histological grade and IHC score of p53. The p53 mutation is also related to the epithelial malignant changes in prostate. Hence, both serum PSA as well as p53 IHC staining can be used as prognostic markers in prostatic neoplasm.

\section{Conclusion}

It is concluded that serum PSA levels in the prostate lesions is upto $4 \mathrm{ng} / \mathrm{ml}$, and all the cases of carcinoma prostate were having serum PSA levels $>4 \mathrm{ng} / \mathrm{ml}$. Also, the serum PSA levels were correlated well with Gleason's grade. The mutation in p53 gene (a tumor suppressor gene) is an important IHC marker in malignant cells. So the IHC expression of p53 is significantly up-regulated in malignant lesions. More research and developments is to be done in this area of tumor suppressor genes and cancer cell biology. 


\section{Acknowlegement}

We are thankful to Dr B K Arora, Professor, Department of Surgery, Pt B D Sharma PGIMS, Rohtak 124001 editing this paper.

\section{References}

[1]. “prostate.”(n.d.). Collins English Dictionary - Complete \& Unabridged 10th Edition. Retrieved by Dictionary.com website: http://dictionary.reference.com/browse/prostate (August 2, 2015)

[2]. McNeal JE. Normal histology of the prostate. Am J Surg Pathol. 1988 Aug;12(8):619-33.

[3]. McVary KT. BPH: epidemiology and comorbidities. Am J Manag Care. 2006;12 (Suppl 5):122-28.

[4]. Epstein JI, Amin M, Boccon-Gibod L, Egevad L, Humphrey PA, Mikuz G, et al. Prognostic factors and reporting of prostate carcinoma in radical prostatectomy and pelvic lymphadenectomy specimens. Scand J Nephrol 2005;216:34-63.

[5]. Malati T, Kumari GR, Murthy PVL, Reddy CR, Prakash BS. Prostate specific antigen in patients of Benign Prostatic Hypertrophy and Carcinoma Prostate. Indian J Biochem 2006;21:34-40.

[6]. Stricker TP, Kumar V. Neoplasia. In: Kumar V, Abbas AK, Fausto N, Aster JC. Robbins and Cotran Pathologic Basis Of Disease $8^{\text {th }}$ Edition. Philadelphia: Saunders; 2010:290-92.

[7]. Tullo A, D'Erchia AM, Sbisa E. Methods for screening tumors for p53 status and therapeutic exploitation. Expert Rev Mol Diagn 2003;3:289-301.162.

[8]. Ross JS, Kallakury BVS, Figge J. Pathology and molecular biology of prostate cancer. In: Rifkin MD, ed. Imaging of the prostate. New York, NY: Lippincott-Raven Press; 1997:179-90.

[9]. Epstein JI, Amin M, Boccon-Gibod L et al. Prognostic factors and reporting of prostate carcinoma in radical prostatectomy and pelvic lymphadenectomy specimens. Scand J Urol Nephrol Suppl. 2005 May;216:34-63.

[10]. Petrescu A, Marzan L, Codreanu O, Niculescu L. Immunohistochemical detection of p53 protein as a prognostic indicator in prostate carcinoma. Rom J Morphol Embroyol 2006;47:143-6.

[11]. Epstein J, Lotan T. The lower urinary tract and male genital system. Saunders: Robbins and Cotran $9^{\text {th }}$ Edition;2015:980-90.

[12]. Clements R, Imaging in prostate carcinoma eMedicine.medscape.com 2010.

[13]. Jones EC, Young RH. The differential diagnosis of prostatic carcinoma. Its distinction from premalignant and pseudocarcinomatous lesion of the prostate gland. Am J Clin Pathol 1994;101:48-64.

[14]. Oppenheimer JR, Wills ML, Epstein JI. Partial atrophy in prostatic needle cores. Another diagnostic pitfall for the surgical pathologist. Am J Surg Pathol 1998;22:440-45.

[15]. Shah R, Mucci NR, Amin A et al. Postatrophic hyperplasia of prostate gland: Neoplastic precursor or innocent bystander? Am J Pathol 2001;158:1767-73.

[16]. Recent advances in urology/andrology: Edinburgh : Churchill Livingstone, 1981

[17]. Goldfarb DA, Stein BS, Shamszadeh M, Petersen RO. Age-related changes in tissue levels of prostatic acid phosphatase and prostate specific antigen. J Urol. 1986 Dec;136(6):1266-9.

[18]. Gjertson CK, Albertsen PC. Use and assessment of PSA in prostate cancer. Med Clin North Am. Jan 2011;95(1):191-200.

[19]. Thompson IM, Pauler DK, Goodman PJ, et al. Prevalence of prostate cancer among men with a prostate-specific antigen level < or $=4.0 \mathrm{ng}$ per milliliter. N Engl J Med 2004;350:2239-46.

[20]. Shih WJ, Collins J, Mitchell B, Wirzbinski B, Lexington BS, Kentucky. Serum PSA and PAP measurements discriminating patient with prostate carcinoma from patient with nodular hyperplasia. J Natl Med Assoc 1994;86:667-70.

[21]. Valeri A, Cormier L, Moineau MP, Cancel-Tassin G, Azzouzi R, Doucet L, et al. Targeted screening for prostate cancer in high risk families: early onset is a significant risk factor for disease in first degree relatives. J Urol. 2002 Aug;168(2):483-7.

[22]. Matikainen MP, Schleutker J, Morsky P, Kallioniemi OP, Tammela TL. Detection of subclinical cancers by prostate-specific antigen screening in asymptomatic men from high-risk prostate cancer families. Clin Cancer Res. 1999 Jun;5(6):1275-9. 